\title{
Is Lightweight Self-Gripping Mesh Effective on Preventing Chronic Groin Pain Following Lichtenstein Tension-Free Herniorrhaphy?
}

\section{Lichtenstein Gerilimsiz Herniorafi Sonrası Kronik Kasik Ağrısını Önlemede Hafif, Kendinden Kavrayan Ağ Etkili Midir?}

\author{
Veysel Barış TURHAN ${ }^{1}(\mathbb{D})$, Alp YILDIZ ${ }^{2}$ (D) , Saadet AKTURAN ${ }^{2}$ (D) , Aybala YILDIZ $^{2}$ \\ ${ }^{1}$ Department of General Surgery, Kecioren Training and Research Hospital, Ankara, Turkey \\ 2 Department of General Surgery, Yenimahalle Training and Research Hospital, Ankara,Turkey
}

Background: Inguinal hernia repair is among the most frequent elective or emergency operations performed in general surgical practice. Lichtenstein hernia repair is considered the gold standard for managing such cases. Postoperative complications especially post-surgical chronic groin pain stands still as a very disabling complication. In this study, we investigated the chronic postoperative pain on 2 different types of meshes.

Materials and Methods: This is a retrospective study evaluating the results of open herniorrhaphy with self gripping mesh or regular prolene mesh. Patients included the study that was male and aged $18-65$ years, which presented with unilateral inguinal hernia and were favorable with Lichtenstein tension-free herniorrhaphy using mesh.

Results: The median duration of the operation was $44.6 \mathrm{~m} \pm 6.1$ on Group- 1 and the median duration of the operation was $24.6 \mathrm{~m} \pm 5.4$ on Group-2, as significantly shorter than Group-1 $(p<0.001)$. The median hospital stay of the patients was 1 day and no statistically significant difference has detected between groups. At follow-up on the third month, the rate of the patients with complaints of mild chronic groin pain in Group- 1 was \% 11.1 vs none in Group$2(p<0.05)$. No recurrence has been detected in both groups after 8.4 months of follow-up.

Conclusions: Our experience of lightwight self-gripping mesh demonstrates that the material is both safe and effective in matters of postoperative complications and recurrence and is very promising in prohibiting chronic groin pain.

Key Words: Tension-free herniorrhaphy, mesh fixation, self-gripping mesh

Öz.

Amaç: Kasık fıtığı onarımı, genel cerrahi pratiğinde en sık yapılan elektif ve acil ameliyatlar arasındadır. Lichtenstein herni onarımı, bu tür vakalar için altın standart olarak kabul edildir. Ameliyat sonrası komplikasyonlar, özellikle ameliyat sonrası kronik kasık ağrısı, oldukça sık bir komplikasyon olarak görülmektedir. Bu çalışmada iki farklı meshin kronik postoperatif ağrıya etkisi araştırıldı.

Materyal ve Metod: Lischtenstein onarımı yapılan hastalarda kendiliğinden kavrayan mesh ve normal prolen mesh sonuçlarını değerlendirdi. Tek taraflı kasık fıtığı ile başvuran ve mesh kullanılarak gerilimsiz herniorafi yapılan 18-65 yaş arası erkek hastalar çalışmaya dahil edildi. Bulgular: Median operasyon süresi Grup-1'de 44,6 $\pm 6,1$ dakika, Grup-2'de 24,6 \pm 5,4 dakika idi. ,Median operasyon süresi Grup-1'den anlamlı olarak daha kısa olarak bulundu( $p<0,001)$. Hastaların hastanede kalış süreleri ortalama 1 gündü ve gruplar arasında istatistiksel olarak anlamlı bir fark saptanmadı. Üçüncü ay takibinde Grup-1'de hafif kronik kasık ağrısı şikayeti olan hasta oranı \%11,1 iken Grup-2'de hiç yoktu $(p<0,05)$. 8,4 aylık takip sonrasında her iki grupta da nüks saptanmadı.

Sonuç: Kendinden kavrayan mesh deneyimimiz, materyalin postoperatif komplikasyonlar ve nüks açısından hem güvenli hem de etkili olduğunu ve kronik kasık ağrısını önleme konusunda çok umut verici olduğunu göstermektedir.

Anahtar kelimeler: Gerilimsiz herniorrafi, mesh fiksasyonu, kendiliğinden kavranan mesh

\section{Corresponding Author / Sorumlu Yazar}

Dr. Veysel Barış TURHAN

Kecioren Training and Research Hospital,

Department of General Surgery Keçiören Ankara/Turkey

E-mail: drbaristurhan@hotmail.com Received / Geliş tarihi: 19.01.2021

Accepted / Kabul tarihi: 04.10.2021

DOI: 10.35440/hutfd.865049 


\section{Introduction}

Thus inguinal herniorrhaphy is amongst the most frequent operations in general surgery (1), the choice for the ideal procedure continues to be an unconsentaneous issue $(1,2)$. Due to the low recurrence margins and low incidence of complications, Lichtenstein tension-free mesh augmented hernioplasty has been accepted as the standard procedure in inguinal hernioplasty2, apparently causing fade in hernia recurrence rates(1-3). Moreover, the rates of chronic postoperative groin pain after a three month-postoperative period are still substantial. In this article we compared selfgripping mesh versus regular polypropylene mesh in respect of chronic postoperative pain.

\section{Materials and Methods}

This is a retrospective study comparing the postoperative results of herniorrhaphy with self gripping mesh or regular prolene mesh. Patients included in the study were males aged between 18 and 65 years, which presented with unilateral inguinal hernia and were eligible for Liechtenstein tension-free open mesh augmented hernia repair. Patients were excluded from this study if they had scrotal, incarcerated, or femoral hernia; had undergone previous laparoscopic inguinal hernia repair; or required emergency procedures. The local ethics committee has approved the study and all patients have signed written informed consent.

The incision has started centering $1 \mathrm{~cm}$ upper and latitude of the inguinal ligament, originated from the pubic bone and reaching out 4-5 cm upper of the mid inguinal line. Subcutaneous tissue has passed through pudendalis superficialis and epigastica superficialis branches of these vessels. The Scarpa fascia is dissected to the aponeurosis of the external oblique muscle, then exposure of the external inguinal ring and the inguinal ligament is completed. The external oblique aponeurosis incised from the external inguinal ring to the upper-lateral for $5-6 \mathrm{~cm}$. Nervus ilioinguinalis has been secured from secondary trauma. Skin flaps prepared and context of spermatic cord with cremaster muscles hung up to ensure the security of these structures and help the exposure of area of herniation.

After exposure, the management of hernia sac;

For Group-1; Polypropylene mesh has been augmented for herniorrhaphy. The patchy edges of the mesh rasped to maintain the optimal adaptation to the prepared area. The mesh has been fixed with 3.0 polypropylene stitches.

For Group-2; a self-gripping polyester mesh for either right or left anatomic position had used and left unfixed.

Hemostasis secured and spermatic cord layers and other anatomical structures have closed concordantly with an anatomic plane.

The patients have been assessed in respect of early and late postoperative pain, and complications. Frequency of analgesic intake, chronic groin pain, paresthesia, hernia recurrence, and duration of operation were recorded.
The Ki-square test has used for statistical analysis was performed by using the software package SPSS 17.0 (IBM Corp. Armonk, NY). A difference with $\mathrm{p}<0.05$ was considered statistically significant.

Ethical approval for this study was obtained from the Clinical Research Ethics Committee of Yıldırım Beyazit University Yenimahalle Training and Research Hospital (16/05/2016-2016/32-2016-05-07)

\section{Results}

A total of 33 patients with the diagnosis of a unilateral primary inguinal hernia has included and evaluated retrospectively by the patient records. 18 patients were used polypropylene mesh (Group-1) and 15 were used self-gripping polyester mesh (Group-2). The two group were evaluated by demographic parameters (mean age: 54.9 years \pm 10.9 vs. 55.2 years \pm 11.3 for Group -1 and Group- 2 respectively: p>0.05), (Table 1).

Table 1. Patient demografic characteristic and outcome of comparison between groups

\begin{tabular}{|c|c|c|c|}
\hline & Group $1(n=18)$ & Group $2(n=15)$ & $p^{*}$ \\
\hline Age & $54.9 \pm 10.9$ & $55.2 \pm 11.3$ & $>0.05$ \\
\hline $\begin{array}{l}\text { Duration of operation, } \\
\text { minute }\end{array}$ & $44.6 \pm 6.1$ & $24.6 \pm 5.4$ & $<0.001$ \\
\hline Hospital stay, day & 1 & 1 & $>0.05$ \\
\hline Complications & $\begin{array}{l}1 \text { (Urinary reten- } \\
\text { tion) }\end{array}$ & none & \\
\hline Analgesic usage & $3.7 \pm 0.8$ & $2.4 \pm 0.9$ & $<0.05$ \\
\hline $\begin{array}{l}\text { Mild chronic groin } \\
\text { pain(\%) }\end{array}$ & 11 & none & $<0.05$ \\
\hline Follow-up,months & $8.4 \pm 0.6$ & $8.2 \pm 0.6$ & $>0.05$ \\
\hline
\end{tabular}

*The Ki-square test, statistically significant results in bold

The median duration of operation was $44.6 \mathrm{~m} \pm 6.1$ on Group-1 and the median duration of the operation was 24.6 $m \pm 5.4$ on Group-2, as significantly shorter than Group-1 $(p<0.001)$.

Median hospital stay for 2 groups is the same as 1 day and no statistically significant difference has been detected between groups.

None patients participating in this study developed any intraoperative or postoperative major complications. Urinary retention has occurred in 1 patient from Group- 1 which dissolved spontaneously on postoperative 6th hour.

The patients from Group-1 used analgesic during follow-up $3.7 \pm 0.8$ times vs. $2.4 \pm 0.9$ times in Group- 2 , and the frequency of analgesic use of patients was significantly higher in Group-1 than Group-2 ( $p<0.05)$.

At follow-up on the third month, the rate of the patients with complaints of mild chronic groin pain in Group-1 was $\% 11.1$ vs none in Group-2( $p<0.05)$.

No recurrence has been detected in both groups after 8.4 months of follow-up. 


\section{Discussion}

Inguinal herniorrhaphy can be considered as the most continual elective operations performed in general surgical practice. Almost $20 \%$ to $30 \%$ of patients with inguinal hernia present even bilateral hernias at diagnosis (4). Lichtenstein tension-free hernia repair with mesh augmentation is considered the gold standard for treating those cases (4-6). Recently, the need for and best way of fixing the mesh have been questioned. Mesh fixation with staples or tacks is widely used and can minimize the risk of mesh displacement, and in additionary, reduce hernia recurrence(4-7). However, fixation is associated with higher costs and can increase the groin pain rates(4-7).

Chronic pain can be restricting and could be overwhelming on patients' quality of life (8). The main cause of post-hernioplasty groin pain is not definite, but it tends to relate to some particular aspects of operative technique, such like gentle handling of the cutaneous nerves, the mesh structure, and the technique used on mesh fixation $(8,9)$. Regular polypropylene meshes have been shown to boost inflammatory responses which can lead to mesh compaction while scar tissue develops. Therefore, it has been advised to augment low-weight meshes and to restrict the area of fixation (8-11). On the other hand, lately, self-gripping meshes have been released, extinguishing the need for aggressive fixation. Several studies showed that the incidence of postoperative pain and wound cite infection were significantly diminished using self-gripping mesh according to polypropylene mesh $(8,15)$.

Technological developments have also lead to the advancement of several types of surgical mesh, such as semi-resorbable structure, self-gripping, fibrin tissue adhesives, and low-weight alternatives (14). This wide range of permitting surgical materials, involved with extensive alternatives of techniques, has led to suspensions for the ideal treatment of inguinal hernia (14-16).

Several synthetic materials were marketed which were proposed for augmentation to the groin, the reliance and effectivity of which were shown by many studies $(17,18)$. It was essential and suggested to secure the mesh at the area of augmentation with additional fixation techniques like tacks, stitches, clips, etc. This ended in the increase of efforts to reduce the aggressive fixation of an augmented mesh with the use of these novel materials marketed (1721). The choice to use self-fixation meshes in inguinal herniorrhaphy was validated on an animal experiment as safe, effective, and easy to manipulate with good implantation to the abdominal wall (17-21).

\section{Conclusion}

In this study, we aimed to evaluate the effect of low-weighted self-gripping mesh on postoperative chronic pain by operating under regional anesthesia with sedation and conform to the basic principles of the Lichtenstein technique.
A self-gripping mesh is low weight mesh, which has tiny hooks to ensure holding the tissue with no need of any additional fixation. Our experience of light-weighted self-gripping mesh demonstrates that the material is both safe and effective in the matters of postoperative complications and recurrence and very promising in prohibiting the chronic groin pain.

Ethical Approval: Ethical approval for this study was obtained from the Clinical Research Ethics Committee of Yıldırım Beyazit University Yenimahalle Training and Research Hospital (16/05/2016-2016/32-2016-05-07)

Author Contributions:

Concept: V.B.T.

Literature Review: V.B.T.

Design : A.Y.(Alp Yıldız)

Data acquisition: S.A

Analysis and interpretation: A.Y.(Aybala Yıldız)

Writing manuscript: V.B.T.

Critical revision of manuscript: A.Y (Aybala Yıldız)

Conflict of Interest: The authors have no conflicts of interest to declare.

Financial Disclosure: Authors declared no financial support.

\section{References}

1. Percalli L, Pricolo R, Passalia L, Riccò M. Comparison between self-gripping, semi re-absorbable meshes with polyethylene meshes in Lichtenstein, tension-free hernia repair: preliminary results from a single center. Acta Biomed. 2018;89(1):72-78.

2. Nikkolo $C$, Vaasna $T$, Murruste $M$, Suumann J, Kirsimägi Ü, Seepter $\mathrm{H}$ et al. Three-year results of a randomized study comparing self-gripping mesh with sutured mesh in open inguinal hernia repair. J Surg Res. 2017;209:139-44.

3. Zwaans WAR, Perquin CW, Loos MJA, Roumen RMH, Scheltinga MRM. Mesh Removal and Selective Neurectomy for Persistent Groin Pain Following Lichtenstein Re- pair. World J Surg 2017;41:701-712.

4. Claus CMP, Rocha GM, Campos ACL, Paulin JAN, Coelho JCU. Mesh Displacement After Bilateral Inguinal Hernia Repair With No Fixation. JSLS. 2017;21(3):17-21

5. Thumbe VK, Evans DS. To repair or not to repair incidental defects found on laparoscopic repair of groin hernia. Surg Endosc. 2001;15:47-49.

6. Griffin KJ, Harris S, Tang TY, Skelton N, Reed JB, Harris AM. Incidence of contralateral occult inguinal hernia found at the time of laparoscopic trans-abdominal pre-peritoneal (TAPP) repair. Hernia. 2010;14:345-349.

7. Wauschkuhn CA, Schwarz J, Boekeler U, Bittner R. Laparoscopic inguinal hernia repair: gold standard in bilateral hernia repair? Results of more than 2800 patients in comparison to literature. Surg Endosc. 2010;24:3026-3030.

8. Wang $Y$, Zhang $X$. Short-term results of open inguinal hernia repair with self-gripping Parietex ProGrip mesh in China: A retrospective study of 90 cases. Asian J Surg. 2016;39(4):218-224.

9. Fountain $\mathrm{Y}$. The chronic pain policy coalition. Bull R Coll Surg Eng. 2006;88:279.

10. Bringman, S, Heikkinen, TJ, Wollert $S$, Österberg J, 
Smedberg S, Granlund, $\mathrm{H}$ et al. Early results of a single-blinded, randomized, controlled, Internet-based multi- center trial comparing Prolene and Vypro II mesh in Lichten- stein hernioplasty. Hernia. 2004;8:127-134.

11. Birk D, Hess S, Garcia-Pardo C. Low recurrence rate and low chronic pain associated with inguinal hernia repair by laparo- scopic placement of Parietex ProGrip" mesh: clinical out- comes of 220 hernias with mean follow-up at 23 months. Hernia. 2013;17:313-320.

12. Kingsnorth, A, Gingell-Littlejohn, $M$, Nienhuijs $S$, Schüle $S$, Appel P, Ziprin, P et al. Randomized controlled multicenter international clinical trial of self-gripping Parietex" ProGrip" polyester mesh versus lightweight polypropylene mesh in open inguinal hernia repair: interim results at 3 months. Hernia. 2012;16:287-294.

13. Cunha-E-Silva JA, Oliveira FMM, Ayres AFSMC, Iglesias ACRG. Conventional inguinal hernia repair with selffixating mesh versus totally extraperitoneal laparoscopic repair with polypropylene mesh: early postoperative results. Rev Col Bras Cir. 2017;44(3):238-244.

14. García Ureña MÁ, Hidalgo M, Feliu X, Velasco MÁ, Revuelta $S$, Gutiérrez $R$ et al. Multicentric observational study of pain after the use of a self-gripping lightweight mesh. Hernia. 2015;15(5):511-5.

15. Hollinsky C, Kolbe T, Walter I, Joachim A, Sandberg S, Koch $T$ et al. Comparison of a new self-gripping mesh with other fixation methods for laparoscopic hernia repair in a rat model. J Am Coll Surg. 2009;208(6):1107-14.

16. Wang $Y$, Zhang $X$. Short-term results of open inguinal hernia repair with self-gripping Parietex ProGrip mesh in China: a retrospective study of 90 cases. Asian J Surg. 2016;39(4):218-24.

17. Klobusicky $P$, Feyerherd P. Usage of a self-adhesive mesh in TAPP hernia repair: A prospective study based on Herniamed Register. J Minim Access Surg. 2016;12(3):226-34.

18. Nowobilski W, Dobosz $M$, Wojciechowicz $T$, Mionskowska L. Lichtenstein inguinal hernioplasty using butyl-2-cyanoacrylate vs. sutures. Preliminary experience of a prospective randomized trial. Eur Surg Res. 2004;36:367-70.

19. Campanelli G, Pascual MH, Hoeferlin A, Rosenberg J, Champault G, Kingsnorth A et al. Randomized controlled, blinded trial of Tisseel/Tissucol for mesh fixation in patients undergoing Lichtenstein technique for primary inguinal hernia repair: Results of the TIMELI trial. Ann Surg. 2012;255:650-7.

20. Shen YM, Sun WB, Chen J, Liu SJ, Wang MG. NBCA medical adhesive (n-butyl-2-cyanoacrylate) versus suture for patch fixation in Lichtenstein inguinal herniorrhaphy: A randomized controlled trial. Surgery. 2012;151:550-5.

21. Bracale U, Rovani M, Picardo A, Merola G, Pignata G, Sodo $M$ et al. Benefitial effects of fibrin glue (Quixil) versus Lichtenstein conventional technique in inguinal hernia repair: A randomized controlled trial. Hernia. 2014;18:185-92. 